\title{
Pembuatan WebGIS Untuk Pemetaan Usaha Mikro Kecil Menengah (UMKM) Di Kabupaten Blitar
}

\author{
Amelia Fadhila dan Agung Budi Cahyono \\ Departemen Teknik Geomatika, Fakultas Teknik Sipil dan Perencanaan,Institut Teknologi Sepuluh \\ Nopember (ITS) \\ e-mail: agungbc@geodesy.its.ac.id
}

\begin{abstract}
Abstrak-Banyak sektor dan faktor untuk mengembangkan pembangunan ekonomi Kabupaten Blitar, salah satunya adalah program dari Dinas Perdagangan dan Perindustrian Kabupaten Blitar untuk memonitoring usaha Mikro kecil dan menengah. Oleh karena itu dibutuhkan solusi dan strategi untuk memonitoring data Usaha Mikro Kecil dan Menengah (UMKM) yang sudah ada dengan dibangunnya suatu sistem informasi geografis berbasis Web yang nantinya juga dapat diakses masyarakat luas. Penelitian ini menggunakan data spasial berupa Koordinat lokasi, Alamat dan data non spasial berupa data dan informasi pendukung berupa nama UMKM, Kategori, Jenis Produk, Alamat, Kontak atau nomor telefon, Pemilik atau penanggung jawab, dan foto UMKM. Pada pembuatan WebGIS UMKM Kabupaten Blitar ini menggunakan Google Maps API sebagai peta dasar. Basisdata yang dibuat pada PHPMyAdmin pada WebGIS ini dibangun berdasarkan data tabular dari Dinas Perindustrian dan Perdagangan, Dinas Koperasi dan UMKM Kabupaten Blitar, serta hasil penelitian lapangan. Halaman WebGIS ini dibangun dengan membuat script menggunakan Sublime Text yang tampil pada localhost. Basisdata dan script halaman di-import ke dalam hosting agar WebGIS dapat tampil secara online pada domain http://umkm- blitar.id . Hasil dari penelitian ini adalah WebGIS Usaha Mikro Kecil da Menengah (UMKM) Kabupaten Blitar yang menyajikan informasi mengenai lokasi, atribut, serta dilengkapi dengan fitur pencarian dan menambah informasi UMKM. Sedangkan dari hasil analisa data didapatkan hasil 908 UMKM yang memiliki Surat Izin Usaha Perdagangan (SIUP) telah memiliki tempat usaha yang tetap, dengan 60 Usaha Mikro Lokasi Koordinat Terdefinisi (UMKT)dan 848 Usaha Mikro Lokasi Koordinat Belum Terdefinisi (UMKBT). Untuk UMKM yang memiliki Izin Usaha Mikro Kecil (IUMK) berjumlah 741 Usaha, dengan 39 merupakan UMKT dan 702 UMKBT.
\end{abstract}

Kata Kunci-Data Spasial Usaha Mikro kecil dan Menengah, Kabupaten Blitar, WebGIS

\section{PENDAHULUAN}

$\mathrm{K}$ ONSTRIBUSI Usaha Mikro Kecil dan Menengah (UMKM) di Indonesia terhadap pembangunan ekonomi Nasional sangatlah besar. Hal ini tercermin dalam penyerapan tenaga kerja yang sangat besar. Karena sektor ini dapat menampung tenaga kerja yang tidak dapat diterima di Usaha berskala besar. UMKM juga diberi perhatian khusus dari pemerintah Kabupaten Blitar, yang terus berbenah diri untuk bersaing dengan daerah lain termasuk menyambut Masyarakat Ekonomi ASEAN, diantaranya dengan pengembangan produk UMKM berbasis pariwisata. Banyak sektor dan faktor untuk mengembangkan pembangunan ekonomi Kabupaten Blitar, salah satunya adalah program untuk memonitoring usaha kecil dan menengah. Dalam mewujudkan dan meningkatkan efisiensi dan efektifitas
(UMKM) yang mandiri dan berkembang, diperlukan sebagai media pendukung yang nantinya dapat berguna sebagai alat untuk mensejajarkan UMKM dengan pelaku usaha lainnya. Dalam hal ini pemanfaatan Tekhnologi Sistem Informasi Geografis (SIG) yang dapat digunakan sepenuhnya di dalam dunia usaha yang tertuang dalam bentuk website di internet guna mempromosikan perusahaan dan produk yang dihasilkan dan informasi lokasi usaha pemilik usaha[1].

Kurangnya informasi mengenai wilayah UMKM itu sendiri juga merupakan salah satu latar belakang mengapa topik ini dipilih. Kegunaan sistem seperti ini dapat menambah pengetahuan bagi masyarakat daerah sekitar mengenai informasi yang di berikan. Diharapkan masyarakat yang membutuhkan informasi mengenai UMKM yang berada di Kabupaten Blitar dapat dengan mudah mengaksesnya secara langsung. Dengan adanya sistem ini, diharapkan warga masyarakat Kabupaten Blitar dapat mengetahui lebih banyak mengenai UMKM di Kabupaten Blitar, memudahkan monitoring serta evaluasi terhadap UMKM oleh pemerintah Kabupaten Blitar, Memudahkan sinkronisasi antar SKPD (Satuan Kerja Perangkat Daerah) dalam menentukan kelompok yang dibina, memudahkan Pemkab Blitar dalam pengelompokan berdasarkan jenis industri, dan mempermudah membentuk klaster ekonomi dan desain rantai pasok dari produk satu ke produk yang lainnya[1].

Pada tahun 2016 Aggraeni juga melakukan penelitian tentang Pembangunan Sistem Informasi Geografis Berbasis Web untuk Pemetaan Industri Kreatif Berbasis Budaya di Kota Surakarta. Pada penelitian ini memanfaatkan jaringan internet sebagai media komunikasi. WebGIS ini menggunakan Google Maps API sebagai peta dasar. Hasil dari penelitian ini adalah WebGIS Industri Kreatif Berbasis Budaya Kota Surakarta yang menyajikan informasi mengenai lokasi, atribut, serta industri kreatif berbasis budaya, serta dilengkapi dengan fitur untuk menambah lokasi dan atribut, memperbaiki atribut, dan mencari industri kreatif berbasis budaya. WebGIS ini telah berhasil membantu mengenalkan lebih jauh tentang Industri Kreatif Surakarta ke masyarakat luas[2].

Karena itu, dalam penelitian Studi ini telah dibuat teknologi SIG dengan Google Maps API untuk menyajikan informasi tentang pembuatan sebuah sistem pemetaan Usaha Mikro Kecil dan Menengah (UMKM) untuk Kabupaten Blitar dengan berbasiskan web sehingga tingkat pemakainnya dapat lebih luas. 


\section{METODOLOGI PENELITIAN}

\section{A. Lokasi Penelitian}

Lokasi penelitian berada di Kabupaten Blitar, Jawa Timur. Kabupaten Blitar berada disebelah Selatan Khatulistiwa yaitu terletak pada $110^{\circ} 40^{\prime}-112^{\circ} 10^{\prime}$ Bujur Timur dan $7^{0} 58^{\prime}-8^{0} 9^{\prime} 5^{\prime \prime}$ Lintang Selatan. dengan batasbatas wilayah sebagai berikut :

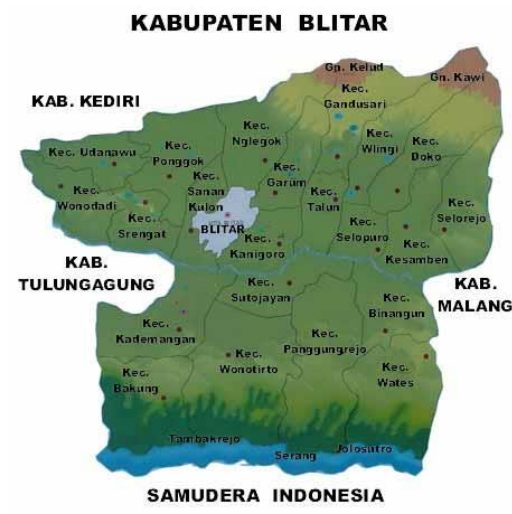

Gambar 1. Peta Lokasi Penelitian

\section{B. Data dan Peralatan}

Adapun peralatan yang digunakan dalam penelitian ini adalah:

1. Perangkat Keras (Hardware)
a. Laptop
b. Printer
c. Kamera Asus Zenfone 3
d. GPS Handheld Oregon 650

2. Perangkat Lunak (Software)
a. Google Maps API untuk penyedia layanan peta online
b. Microsoft Office untuk pembuatan laporan
c. Microsot Excel untuk pengumpulan basisdata awal
d. Microsoft Visio untuk pembuatan diagram alir, dan diagram ERD
e. Sublime untuk pembuatan script
f. XАMPP untuk mengkonfigurasikan Web-Server apache, PHP, dan MySQL
g. PhpMyAdmin untuk penyimpanan basisdata
h. Html Php MySQL untuk bahasa pemrograman

\section{Tahapan Pengolahan Data}

Tahapan pengolahan data pada penelitian ini adalah sebagai berikut:

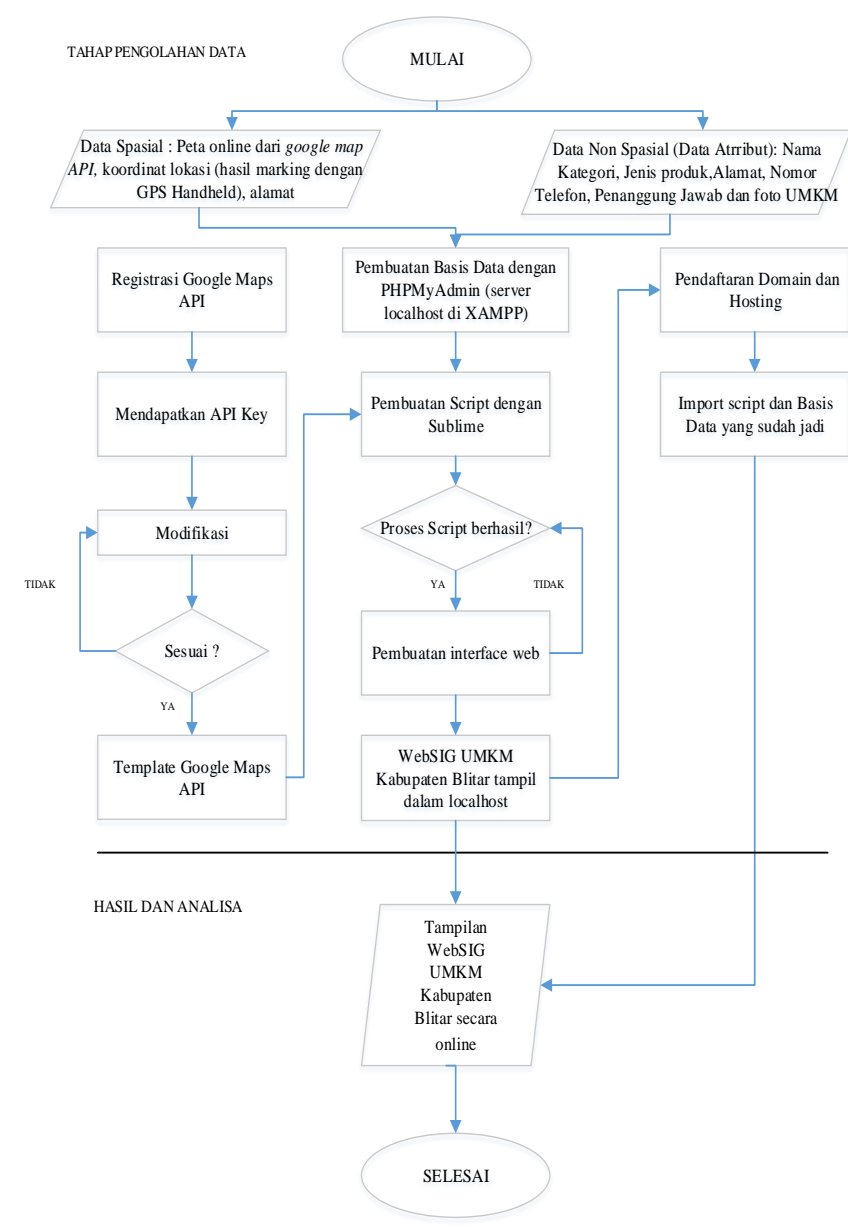

Gambar 2. Diagram Alir Tahapan pengolahan Data

\section{HASIL DAN ANALISA}

\section{A. Pembuatan Basisdata}

Basisdata yang telah dirancang lalu dibangun dengan perangkat lunak PHPMyAdmin. Dengan perangkat lunak PHPMyAdmin, seseorang dapat membuat basisdata, membuat tabel, mengisi data, dan lain-lain dengan mudah, tanpa harus menghafal baris perintahnya. Basisdata dalam PHPMyAdmin merupakan implementasi dari desain basisdata yang sudah dibuat melalui tahap model konsepsual, model logikal, dan model fisikal.

\section{B. Pembuatan Template Google Maps API Template Google Maps API}

Template Google Maps API merupakan kode (javascript ditambah html) awal yang disediakan oleh Google untuk memudahkan pengguna dalam mengembangkan peta sesuai dengan keinginan pengguna.

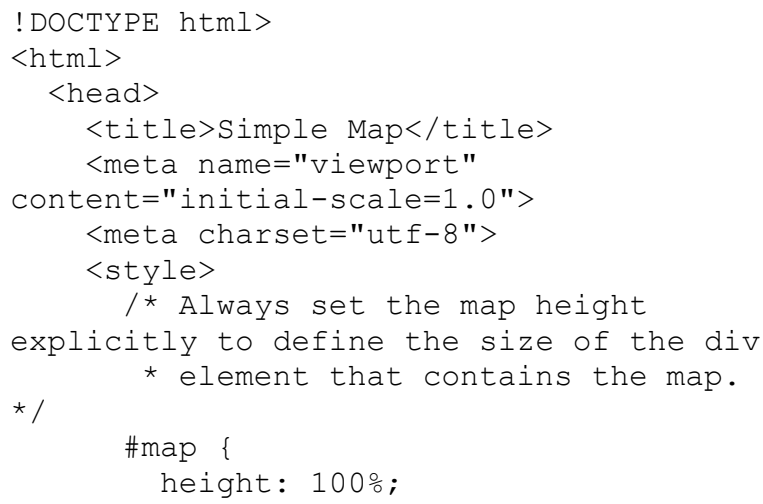




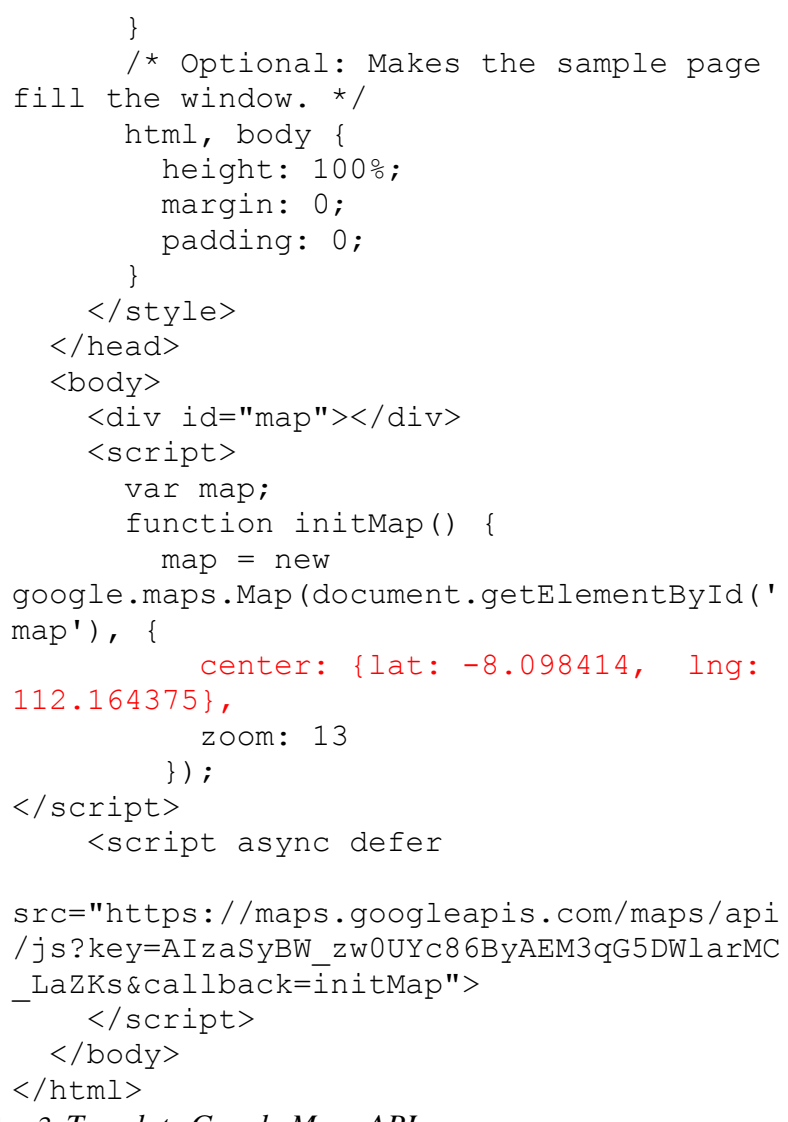

Gambar 3. Template Google Maps API

Fungsi nilai center (-8.098414, 112.164375) untuk menampilkan Kabupaten Blitar pada peta.

\section{Pengolahan Data Tabular}

Data non spasial atau tabular yang digunakan dalam Studi ini adalah data Usaha Mikro Kecil dan Menengah di Kabupaten Blitar yang merupakan jenis permohonan IUMK (Izin Usaha Mikro Kecil) baru yang terdaftar mulai tahun 2014 dari Dinas Perdagangan dan Perindustrian Kabupaten Blitar, data tabular Kelompok Usaha bersama yang pernah dibina pemerintah Kabupaten Blitar, serta data koordinat hasil dari pengambilan langsung di lapangan dan di kombinasikan dengan pencarian di Google Maps. Kemudian data yang diperoleh digabungkan sebagai database

\section{Tampilan Halaman WebGIS}

WebGIS ini akan tampil secara online pada domain http://umkm-blitar.id. Yang terdiri dari halaman-halaman antara lain halaman utama Home, Sub Halaman FAQ, Peta yang didalamnya terdapat rincian informasi, petunjuk arah, selanjutnya ada sub halaman Tentang Kategori, Tambahi Informasi, Admin, dan Logout.

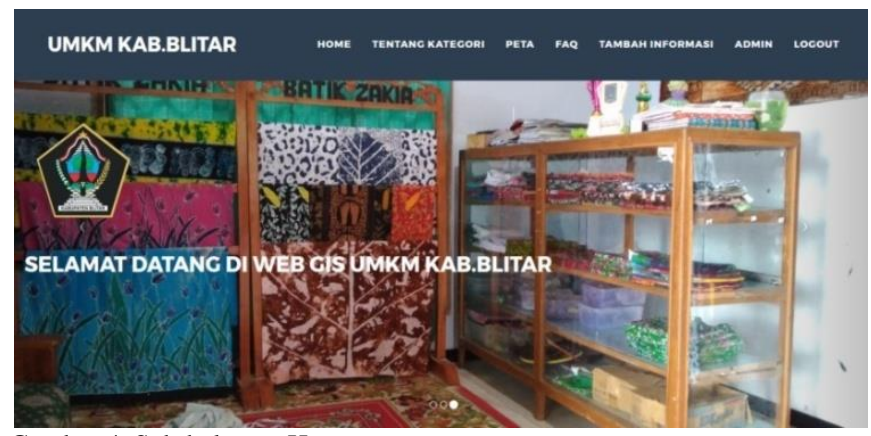

Gambar 4. Sub-halaman Home

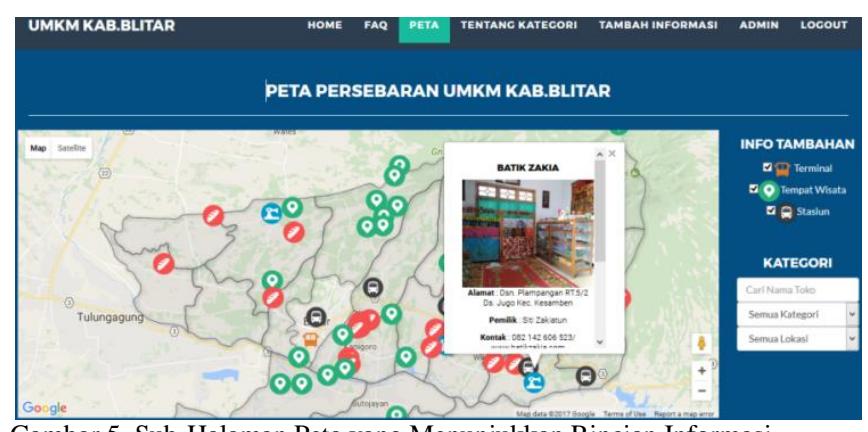

Gambar 5. Sub-Halaman Peta yang Menunjukkan Rincian Informasi

\section{1) $F A Q$}

Sub-halaman F.A.Q atau frequently asked question seperti yang ditunjukkan Gambar 6, berisikan tujuan serta cara pengoperasian dari web ini. F.A.Q terdiri atas pertanyaanpertanyaan dan jawaban dari masing-masing pertanyaan yang akan sering dipertanyakan oleh pengguna pemula.

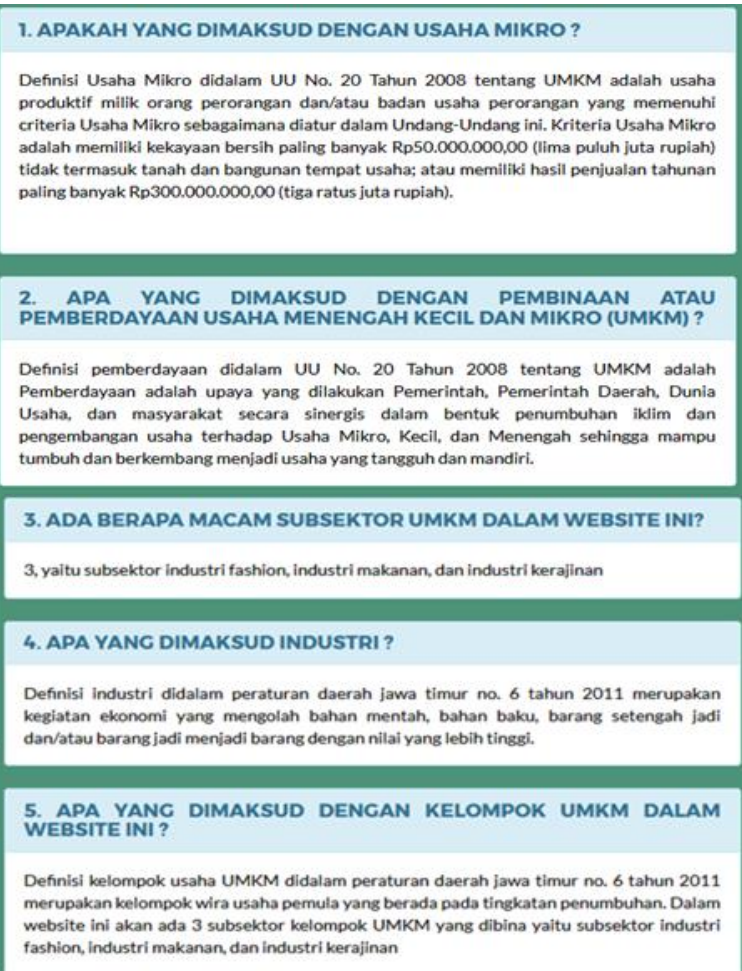

Gambar 6. Sub-halaman F.A.Q

\section{2) Halaman Login}

Admin dan user masuk ke dalam sistem melalui halaman login (Gambar 7) yang sama, username dan password yang dimasukkan nantinya yang akan menentukan peran (admin atau user). Pada halaman login juga terdapat tombol daftar.

Gambar 7. Halaman Login

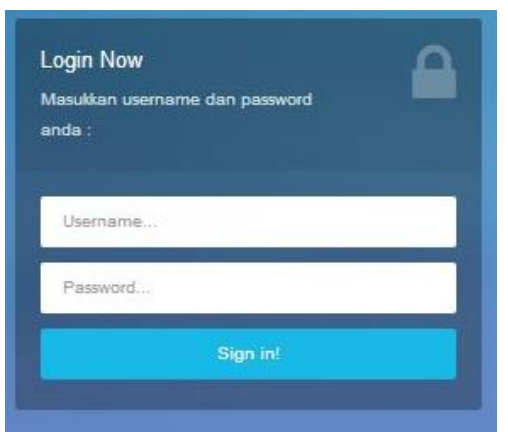




\section{3) Halaman Regristrasi}

Admin melakukan registrasi dengan langsung mengisi pada basisdata pada PhpMyAdmin. Sedangkan, user dapat melakukan registrasi dengan memasukkan username, dan password pada halaman daftar (Gambar 8). Untuk menuju ke halaman daftar, user harus melewati halaman login untuk menemukan tombol daftar.

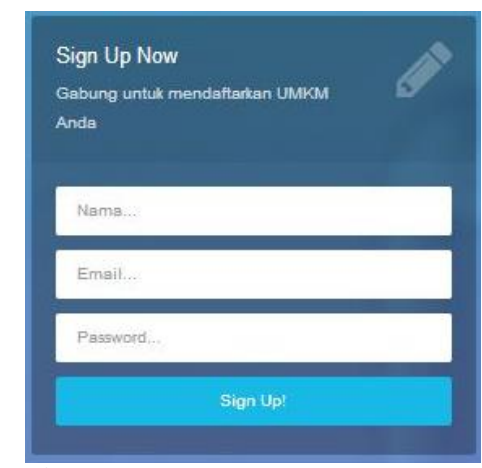

Gambar 8. Halaman Daftar

\section{4) Halaman Admin}

Admin mempunyai kewenangan untuk menyetujui maupun menolak informasi UMKM yang ditambahkan oleh user. Admin akan menerima atau menyimpan informasi dari user yang layak untuk dipubikasikan dengan klik simbol terima $(\checkmark)$. Admin memiliki kewenangan untuk menghapus informasi dari user yang tidak layak untuk dipublikasikan dengan klik simbol tolak $(\stackrel{x}{ })$.
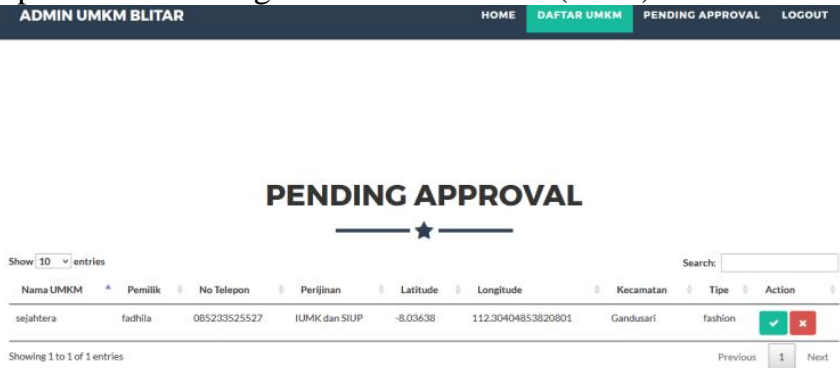

Gambar 9 Sub-halaman Daftar Request

\section{5) Halaman Tambah Informasi}

User dapat menambah lokasi Usaha Mikro Kecil Menengah serta informasi pendukung dengan klik tombol Add Informasi pada sub-halaman peta di halaman utama. Namun, user hanya bisa menambah lokasi sesuai dengan jenis atau kategori yang telah disediakan pada drop down Kategori UMKM.

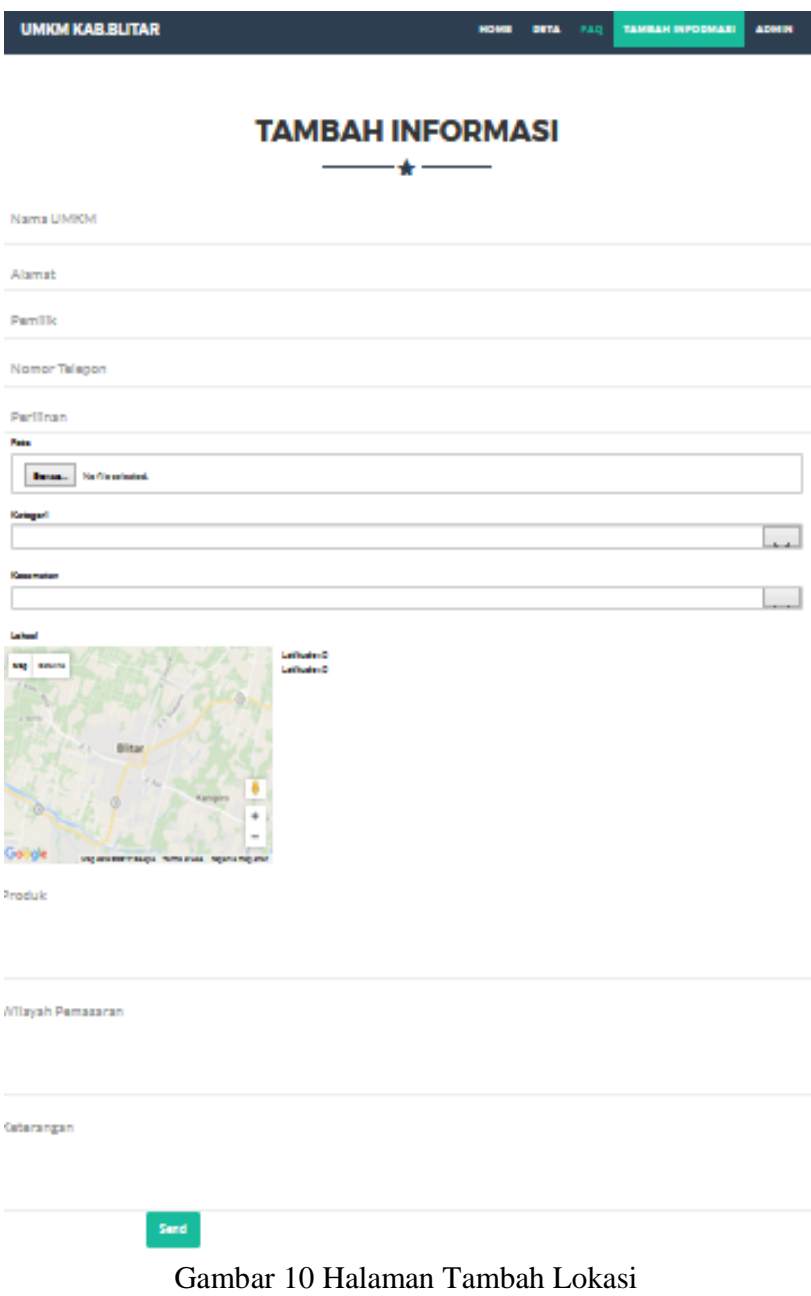

\section{E. Analisa Data}

Berdasarkan Ijin Surat Izin Usaha Perdagangan (SIUP) dinas KPTSP Kabupaten Blitar terhitung mulai 1 Januari 2014 sampai dengan 13 Maret 2017 jumlah Usaha Mikro Kecil Menengah yang sudah terdaftar berjumlah 938 UMKM. Dari 938 UMKM Mikro tersebut 908 memiliki alamat tempat usaha, sedangkan 30 tidak memiliki alamat tempat usaha.

Tabel 1.

Tabel UMKM yang memiliki SIUP

\begin{tabular}{lrrr}
\hline & & & Jumlah \\
Kecamatan & UMKT & UMKBT & UMKM \\
\hline Udanawu & 3 & 19 & 22 \\
Selorejo & 1 & 22 & 23 \\
Talun & 2 & 39 & 41 \\
Sanankulon & 0 & 42 & 42 \\
Wlingi & 10 & 37 & 47 \\
Kademangan & 3 & 52 & 55 \\
Wonodadi & 1 & 29 & 30 \\
Kesamben & 2 & 37 & 39 \\
Bakung & 2 & 48 & 50 \\
Kanigoro & 6 & 105 & 111 \\
Ponggok & 7 & 82 & 89 \\
Gandusari & 1 & 22 & 23 \\
Wonotirto & 0 & 26 & 26 \\
Srengat & 5 & 66 & 71 \\
Wates & 2 & 7 & 9 \\
Sutojayan & 7 & 41 & 48 \\
Binangun & 0 & 15 & 15 \\
Garum & 2 & 44 & 46 \\
Nglegok & 4 & 19 & 23 \\
Panggungrejo & 0 & 24 & 24 \\
Selopuro & 0 & 26 & 26 \\
Doko & 2 & 46 & 48 \\
Jumlah & $\mathbf{6 0}$ & $\mathbf{8 4 8}$ & $\mathbf{9 0 8}$ \\
\hline \hline
\end{tabular}


Tabel 2.

Tabel Definisi Koordinat UMKM yang memiliki SIUP

\begin{tabular}{lr}
\hline \hline \multicolumn{1}{c}{ Jenis Usaha } & Jumlah \\
\hline Usaha Mikro Lokasi Koordinat Terdefinisi & 60 \\
(UMKT) & \\
$\begin{array}{l}\text { Usaha Mikro Lokasi Koordinat Belum } \\
\text { Terdefinisi (UMKBT) } \\
\quad \text { Jumlah }\end{array}$ & 848 \\
\hline \hline
\end{tabular}

Sedangkan berdasarkan Laporan Hasil Pemberian Izin Usaha Mikro Kecil ( IUMK ) dinas Perindustrian dan Perdagangan ( Disperindag ) Kabupaten Blitar sampai Desember 2016 jumlah Usaha Mikro Kecil Menengah yang sudah terdaftar berjumlah 741 UMKM. Berikut adalah tabel sebaran UMKM di Kabupaten Blitar yang sudah mendapatkan ijin IUMK :

Tabel 3 .

UMKM yang memiliki IUMK

\begin{tabular}{lcrr}
\hline Kecamatan & UMKT & UMKBT & Jumlah \\
\hline Udanawu & 0 & 60 & 60 \\
Selorejo & 0 & 18 & 18 \\
Talun & 2 & 20 & 22 \\
Sanankulon & 2 & 38 & 40 \\
Wlingi & 8 & 57 & 65 \\
Kademangan & 1 & 43 & 44 \\
Wonodadi & 2 & 36 & 38 \\
Kesamben & 2 & 46 & 48 \\
Bakung & 0 & 1 & 1 \\
Kanigoro & 2 & 48 & 50 \\
Ponggok & 1 & 18 & 19 \\
Gandusari & 2 & 32 & 34 \\
Wonotirto & 2 & 14 & 16 \\
Srengat & 5 & 36 & 41 \\
Wates & 0 & 0 & 0 \\
Sutojayan & 4 & 74 & 78 \\
Binangun & 0 & 12 & 12 \\
Garum & 2 & 21 & 23 \\
Nglegok & 2 & 54 & 56 \\
Panggungrejo & 0 & 26 & 30 \\
Selopuro & 2 & & $\mathbf{7 4 1}$ \\
Doko & 0 & 39 & \\
Jumlah & & & \\
\hline \hline
\end{tabular}

Tabel 4.

Tabel Definisi Koordinat UMKM yang memiliki IUMK Jenis Usaha Jumlah

Usaha Mikro Lokasi Koordinat Terdefinisi (UMKT)

Usaha Mikro Lokasi Koordinat Belum 702 Terdefinisi (UMKBT) Jumlah

F. Analisa Kepadatan Usaha Mikro Kecil Menengah

Berikut analisa jumlah usaha dan luas wilayah berdasarkan Direktori Perusahaan Industri Kecil Menengah Kabupaten Blitar Tahun 2016. Kondisi jumlah usaha ini akan mempengaruhi nilai kepadatan usaha kecil dan menengah di luasan per wilayah. Berikut adalah perhitungan kepadatannya sesuai dengan rumus hitungan (1):
Nilai Kepadatan $=\frac{\text { Jumlah Obyek }}{\text { Luas Wilayah }}$

Tabel 5.

Nilai Kepadatan UMKM

\begin{tabular}{lrrr}
\multicolumn{4}{c}{ Nilai Kepadatan UMKM } \\
\hline \hline Kecamatan & $\begin{array}{r}\text { Jumlah } \\
\text { UMKM }\end{array}$ & $\begin{array}{c}\text { Luas Wilayah } \\
(\mathrm{m} 2)\end{array}$ & $\begin{array}{c}\text { Nilai } \\
\text { Kepadatan }\end{array}$ \\
\hline Udanawu & 291 & 40.980 .000 & 7,101 \\
Selorejo & 850 & 52.230 .000 & 1,627 \\
Talun & 831 & 4.978 .000 .000 & 1,669 \\
Sanankulon & 1.469 & 33.330 .000 & 4,407 \\
Wlingi & 796 & 66.360 .000 & 1,199 \\
Kademangan & 788 & 105.280 .000 & 7,485 \\
Wonodadi & 139 & 40.350 .000 & 3,445 \\
Kesamben & 362 & 56.960 .000 & 6,355 \\
Bakung & 1.194 & 111.240 .000 & 1,073 \\
Kanigoro & 998 & 55.550 .000 & 1,796 \\
Ponggok & 2.635 & 103.830 .000 & 2,538 \\
Gandusari & 995 & 88.230 .000 & 1,128 \\
Wonotirto & 255 & 164.540 .000 & 1,549 \\
Srengat & 703 & 53.980 .000 & 1,302 \\
Wates & 606 & 68.760 .000 & 8,813 \\
Sutojayan & 425 & 44.200 .000 & 9,615 \\
Binangun & 308 & 76.790 .000 & 4,011 \\
Garum & 888 & 54.560 .000 & 1,628 \\
Nglegok & 3.255 & 92.560 .000 & 3,517 \\
Panggungrejo & 181 & 119.040 .000 & 1,521 \\
Selopuro & 506 & 39.290 .000 & 1,288 \\
Doko & 382 & 70.950 .000 & 5,384 \\
\hline & & & \\
\hline
\end{tabular}

Dari hasil nilai kepadatan tersebut dapat disimpulkan bahwa Kecamatan Sutojayan memiliki nilai kepadatan yang paling tinggi dengan nilai 9,615 unit $\mathrm{UMKM} / \mathrm{m}^{2}$. Dan Kecamatan Bakung memiliki nilai kepadatan yang paling rendah dengan 1,073 unit $\mathrm{UMKM} / \mathrm{m}^{2}$.

\section{KESIMPULAN}

Telah dibuat WebGIS yang memiliki kemampuan untuk menampilkan informasi persebaran UMKM di Kabupaten Blitar serta informasi pendukung melalui peta online Google Maps. Terdapat 45 titik Usaha Mikro, 35 titik tempat wisata, 6 titik stasiun kereta api, dan 1 titik Terminal Bus yang tersebar diwilayah Kabupaten Blitar.

Dalam perhitungan pembagian total jumlah 908 Usaha UMKM yang memiliki Surat Izin Usaha Perdagangan (SIUP) telah memiliki tempat usaha yang tetap, 30 UMKM belum memiliki tempat usaha yang tetap, dengan 60 Usaha Mikro Lokasi Koordinat Terdefinisi (UMKT) dan 848 Usaha Mikro Lokasi Koordinat Belum Terdefinisi (UMKBT). Untuk UMKM yang memiliki Izin Usaha Mikro Kecil (IUMK) berjumlah 741 Usaha, dengan 39 merupakan UMKT dan 702 UMKBT.

\section{UCAPAN TERIMAKASIH}

Penulis mengucapkan terimakasih kepada Dinas Koperasi dan UMKM Kabupaten Blitar, Dinas Perdagangan dan Perindustrian, dan Dinas Penanaman Modal dan PTSP Kabupaten Blitar yang telah memberikan bantuan berupa data. 


\section{DAFTAR PUSTAKA}

[1] P. K. Blitar, "Gambaran Umum," 2012. [Online]. Available: url:http://www.blitarkab.go.id/2012/06/06/gambaran-umum.

[2] A. Anggraeni, "Pembangunan Sistem Informasi Geografis Berbasis Web untuk Pemetaan Industri Kreatif Berbasis Budaya di Kota Surakarta,” Inst. Teknol. Sepuluh Nop., 2016. 